\title{
Two-Year Outcome After Angiographically Documented Myocardial Reperfusion for Acute Coronary Occlusion
}

\author{
David W.M. Muller, MBBS, Eric J. Topol, MD, Barry S. George, MD, Dean J. Kereiakes, MD, \\ Lynn G. Aronson, MS, Kerry L. Lee, PhD, Charles W. Abbottsmith, MD, Stephen G. Ellis, MD, \\ Robert M. Califf, MD, and the Thrombolysis and Angioplasty Study Group
}

\begin{abstract}
Reperfusion therapy has been clearly shown to decrease the early mortality after acute myocardial infarction, but the impact of this therapy on longterm survival has been less extensively evaluated. This study reports the extended follow-up of a large cohort of 810 patients treated with intravenous thrombolytic therapy combined, when considered necessary to maintain or augment infarct vessel patency, with mechanical reperfusion therapies. Each patient underwent coronary angiography within 2 hours of the initiation of the thrombolytic infusion. Coronary angioplasty was performed in $62 \%$ of the patients before hospital discharge and $21 \%$ underwent coronary artery bypass graft surgery. Follow-up was obtained in $96 \%$ to a mean of 18.8 months (range, 1.5 to 48 months). All-cause mortality over this period was $3.3 \% ; 2.1 \%$ died from cardiac causes. Nonfatal reinfarction occurred in $5.1 \%$. Although the low event rate limits the validity of statistical comparisons, the patients who survived the follow-up period tended to be younger ( $56 \pm 10$ vs $65 \pm 7$ years), to have better predischarge left ventricular function (left ventricular ejection fraction, $52 \pm 11$ vs $46 \pm 13 \%$ ) and to have a lower prevalence of multivessel coronary artery disease (45 vs 67\%). This excellent long-term survival may, in part, reflect the exclusion of highrisk patients from enrollment in the Thrombolysis and Angioplasty in Myocardial Infarction (TAMI) studies. It may also be attributable, however, to the frequent use of combined thrombolysis and mechanical revascularization in this population.
\end{abstract}

(Am J Cardiol 1990;66:796-801)

From the Division of Cardiology, Department of Internal Medicine, University of Michigan Medical Center, Ann Arbor, Michigan. Manuscript received March 14, 1990; revised mansucript received and accepted May 15, 1990.

Address for reprints: Eric J. Topol, MD, Division of Cardiology, University of Michican Medical Center, B1 F245, 1500 East Medical Center Drive, Ann Arbor, Michigan 48109-0022.
D uring the past 2 decades, the in-hospital mortality rate from acute myocardial infarction has decreased progressively. This has been due, firstly, to the impact of cardiac monitoring and the rapid treatment of cardiac arrhythmias and, secondly, to the shift in emphasis from therapeutic strategies aiming to decrease myocardial work and oxygen demand to therapies that actively restore myocardial oxygen supply. Several randomized, controlled trials have reported 30 day mortality rates ranging from 5.0 to $10.7 \%^{1-4}$ after reperfusion therapy. This compares with early fatality rates of $16 \%$ for hospitalized men and $28 \%$ for women in the Framingham Study, ${ }^{5}$ a study performed before the widespread use of antiplatelet and $\beta$-adrenergic blocking therapy and before the use of thrombolytic therapy, direct coronary angioplasty and emergency coronary artery bypass graft surgery.

Since January 1985, the Thrombolysis and Angioplasty in Myocardial Infarction (TAMI) study group has evaluated myocardial reperfusion strategies using intravenous thrombolysis and adjunctive medical therapies combined, when considered appropriate, with coronary angioplasty. The impact of thesc stratcgies on lcft ventricular functional recovery and on in-hospital mortality, ${ }^{6-11}$ and the 1-year outcome of the 386 patients in the first TAMI study ${ }^{12}$ have been previously reported. This study examines the clinical outcome over a more extended follow-up period of the larger cohort of patients enrolled in the first 4 TAMI studies.

\section{METHODS}

Patient selection: Between January 1985 and March 1988, 810 patients were enrolled in 4 phases of the TAMI study. The study protocols were similar for each phase and have been previously published. ${ }^{71} \mathrm{~Pa}-$ tients were eligible for enrollment if they presented within 6 hours of the onset of chest pain and had $\geq 0.1$ $m V$ ST-segment elevation in $\geq 2$ contiguous electrocardiographic leads or ST-segment depression in the precordial leads consistent with posterior wall infarction. Patients were ineligible if they had contraindications to thrombolytic therapy, were $\geq 76$ years of age, had a history of prior coronary artery bypass graft surgery or Qwave myocardial infarction in the same territory as the acute event or were in cardiogenic shock (defined as a systolic blood pressure $<85 \mathrm{~mm} \mathrm{Hg}$ that was unresponsive to the administration of intravenous fluids). 
TABLE I Baseline Demographic and Angiographic Characteristics of the Hospital Survivors with Complete Follow-Up Data $(n=727)$

\begin{tabular}{lc|} 
Sex (\% men) & 82 \\
Age (yrs) & $56 \pm 10$ \\
Risk factors (\%) & \\
$\quad$ Diabetes mellitus & $14 \%$ \\
$\quad$ Systemic hypertension & $40 \%$ \\
$\quad$ Hyperlipidemia & $12 \%$ \\
$\quad$ Cigarette smoking & $65 \%$ \\
Vascular disease & \\
$\quad$ Cerebral & $2 \%$ \\
$\quad$ Peripheral & $5 \%$ \\
Time to therapy & $176 \pm 66 \mathrm{~min}$ \\
Infarct-related artery & \\
$\quad$ Left anterior descending & $39 \%$ \\
Right coronary artery & $48 \%$ \\
Left circumflex & $12 \%$ \\
$\quad$ Other & $0.3 \%$ \\
Acute angiography & \\
Left ventricular ejection fraction & $51 \pm 11 \%$ \\
Multivessel disease & $45 \%$
\end{tabular}

Treatment regimen: The thrombolytic agents used were recombinant tissue plasminogen activator (tPA) and urokinase, given alone or in combination..$^{7-10}$ In 1 phase, tPA was combined with intravenous prostacyclin. " All patients received oral aspirin and intravenous heparin for $\geq 4$ days after admission and the majority received intravenous nitroglycerin and prophylactic intravenous lidocaine. Oral diltiazem and $\beta$-adrenergic blocking agents were given as clinically indicated for hypertension, arrhythmias or recurrent myocardial ischemia. Cardiac catheterization was performed within 90 minutes of the initiation of the thrombolytic therapy to document baseline global and regional left ventricular function and to determine the patency status of the infarct vessel. Rescue angioplasty was performed if the infarct vessel remained occluded (Thrombolysis in Myocardial Infarction [TIMI] flow grade 0 or 1). Patients with TIMI 2 or 3 flow in the infarct vessel and suitable anatomy were randomized in the first phase to either immediate or to deferred angioplasty of residual infarct vessel stenoses. In subsequent phases, angioplasty of the infarct vessel was performed acutely only if it remained occluded 90 minutes after the initiation of the thrombolytic therapy. Cardiac catheterization was repeated before hospital discharge to evaluate changes in global and regional left ventricular function and infarct vessel patency. Coronary angioplasty of residual stenoses in the infarct-related artery was performed at the time of the predischargc cardiac cathetcrization if submaximal exercise thallium testing showed evidence of reversible ischemia in the infarct territory and the coronary anatomy was deemed suitable for the procedure. Intercurrent coronary angiography was also performed for symptoms of recurrent myocardial ischemia or hemodynamic instability. Emergency coronary artery bypass graft surgery was performed for ongoing myocardial ischemia when the infarct vessel subserved a large myocardial territory and was either unsuitable for coronary angioplasty because of the presence of left

\begin{tabular}{|c|c|}
\hline \multicolumn{2}{|c|}{$\begin{array}{l}\text { TABLE II Predischarge Treatment of Hospital Survivors wit } \\
\text { Complete Follow-Up }\end{array}$} \\
\hline Thrombolytic agent & \\
\hline Tissue plasminogen activator & $69 \%$ \\
\hline Urokinase & $13 \%$ \\
\hline Tissue plasminogen activator + urokinase & $18 \%$ \\
\hline \multicolumn{2}{|l|}{ Predischarge coronary angioplasty } \\
\hline Acute & $42 \%$ \\
\hline Emergency & $8 \%$ \\
\hline Elective & $25 \%$ \\
\hline \multicolumn{2}{|l|}{ Predischarge coronary artery bypass surgery } \\
\hline Emergency & $6 \%$ \\
\hline Urgent & $6 \%$ \\
\hline Elective & $10 \%$ \\
\hline \multicolumn{2}{|l|}{ Infarct vessel patency at discharge } \\
\hline Patent (TIMI 2,3) & $63 \%$ \\
\hline Occluded (TIMIO O.1) & $8 \%$ \\
\hline Surgically bypassed & $22 \%$ \\
\hline Unknown & $7 \%$ \\
\hline
\end{tabular}

main (or equivalent) coronary artery disease or extreme tortuosity or if patency of the infarct vessel could not be achieved and maintained after intravenous thrombolytic therapy and balloon dilatation. ${ }^{13}$ Urgent coronary artery graft surgery was performed for recurrent myocardial ischemia and elective surgery for provocable ischemia when the coronary anatomy precluded coronary angioplasty.

Follow-up: Regular follow-up was performed after hospital discharge by telephone and mailed questionnaire. The events recorded included death, nonfatal myocardial infarction, functional class (Canadian Heart Association Classification) and postdischarge coronary angioplasty or coronary artery bypass graft surgery. The timing and cause of death were determined when possible by examination of death certificates and reports of postmortem studies. Events leading to rehospitalization were determined by the study nurse during followup contact and by examination of hospital records.

Statistics: All values are quoted as mean \pm 1 standard deviation unless otherwise stated. A Kaplan-Meier estimate was used to construct a curve of long-term outof-hospital survival. Statistical comparisons of baseline characteristics and outcomes between groups were not made because of the low event rate and the observational nature of the data.

\section{RESULTS}

Patient characteristics: Baseline characteristics of the patients surviving to hospital discharge are listed in Table 1. The use of thrombolytic therapy, predischarge coronary angioplasty and bypass graft surgery, and the patency status of the infarct-related artery are listed in Table II. Of the 810 patients, 757 were discharged from the hospital alive. Follow-up has been obtained on 727 (96\%) of these to a mean of 18.8 months (25th, 75th percentiles; 13.3, 24.4 months). The age of the patients surviving to hospital discharge was $56 \pm 10$ years; $82 \%$ were men. Mean predischarge global left ventricular ejection fraction was $51 \% ; 25 \%$ of the patients had an 
TABLE III Baseline Characteristics of Patients Alive at Last Follow-Up Compared with Non-Survivors.

\begin{tabular}{|c|c|c|}
\hline & $\begin{array}{l}\text { Survivors } \\
(n=703)\end{array}$ & $\begin{array}{l}\text { Non- } \\
\text { Survivors } \\
(n=24)\end{array}$ \\
\hline Sex $(\%$ men $)$ & 82 & 79 \\
\hline Age (yrs) & $56 \pm 10$ & $65 \pm 7$ \\
\hline \multicolumn{3}{|l|}{ Infarct vessel status at discharge } \\
\hline Coronary artery bypass graft & $22 \%$ & $20 \%$ \\
\hline TIMI 2 or 3 & $63 \%$ & $67 \%$ \\
\hline TIMIOor 1 & $8 \%$ & $0 \%$ \\
\hline Unknown & $7 \%$ & $13 \%$ \\
\hline \multicolumn{3}{|l|}{$\begin{array}{l}\text { No. of diseased vessels (acute } \\
\text { catheterization) }\end{array}$} \\
\hline 0 to 1 & $55 \%$ & $33 \%$ \\
\hline 2 to 3 & $45 \%$ & $67 \%$ \\
\hline Predischarge left ventricular ejection fraction & $52 \pm 11 \%$ & $46 \pm 13 \%$ \\
\hline
\end{tabular}

ejection fraction $<43 \%$. The infarct vessel was patent at discharge or had been surgically bypassed in $85 \%$, was occluded in $8 \%$ and its status was unknown in the remaining $7 \%$.

During the follow-up period, 24 deaths occurred. Figure 1 shows the survival curve, projected to 2 years, of patients discharged from the hospital alive. The cause of out-of-hospital death was cardiac in 15 patients (2.1\%) and noncardiac, predominantly due to disseminated malignancy, in 9 patients (1.2\%). Nonfatal recurrent myocardial infarction occurred in $5.1 \%$, coronary angioplasty was performed after hospital discharge in $7.4 \%$ and $5.4 \%$ underwent elective coronary artery bypass graft surgery (Figure 2). Comparison of the patients surviving the follow-up period with the non-survivors (Table III) shows that there was no apparent difference in sex distributions or infarct vessel patency status between the 2 groups. However, the non-survivors tended to be older, to have worse left ventricular function and more extensive coronary artery disease. Subgroup analysis of out-of-hospital events according to the patency status of the infarct-related artery is listed in Table IV. Surprisingly, no deaths were recorded in the group of 54 patients with non-patent infarct vessels. The mortality rate for patients with patent infarct vessels was $3 \%$ and for those with unknown patency status was $5 \%$.

\section{DIscussion}

The principal finding of this study is that an aggressive strategy of early intravenous thrombolysis combined with mechanical revascularization for residual or
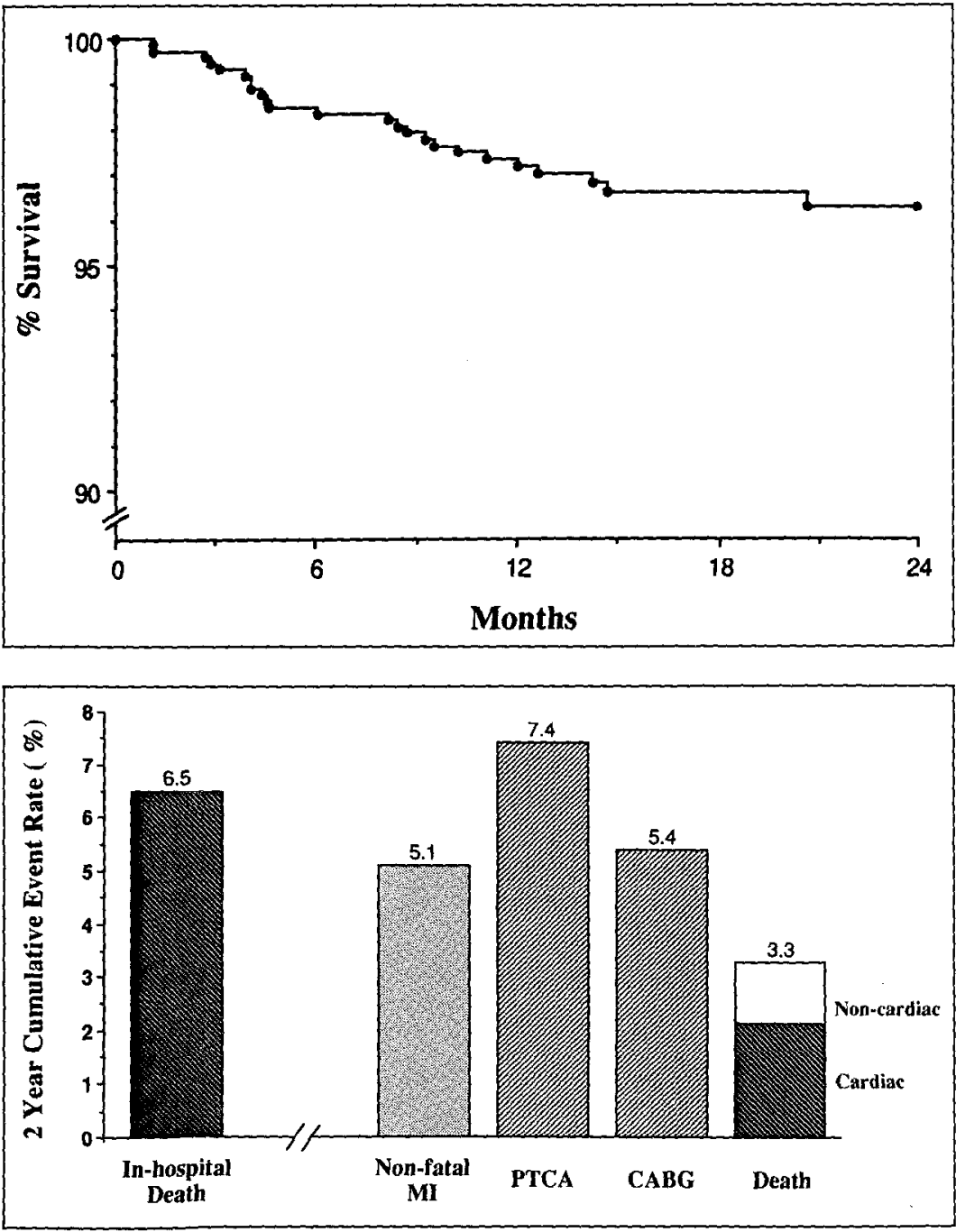

FIGURE 1. Kaplan-Meier survival curve for patients discharged from hospital alive (n = 757)

FIGURE 2. Bar graphs showing in-hospital mortality for total population $(n=$ 810), and out-of-hospital mortality, nonfatal reinfarction rate and need for revascularization procedures during follow-up period in population of hospital survivors (n $=757)$. CABG $=$ coronary artery bypass graft; $M=$ myocardial infarction; PTCA = percutaneous transluminal coronary angioplasty. 
TABLE IV Baseline Characteristics and Outcome According to Patency of Infarct-Related Artery (IRA) at Hospital Discharge

\begin{tabular}{|c|c|c|c|}
\hline & $\begin{array}{l}\text { Patent IRA } \\
(n=610)\end{array}$ & $\begin{array}{l}\text { Non-Patent } \\
\text { IRA } \\
(\mathrm{n}=58)\end{array}$ & $\begin{array}{l}\text { Unknown Status } \\
(n=57)\end{array}$ \\
\hline Sex $(\%$ men $)$ & 83 & 84 & 68 \\
\hline Age (yrs) & $56 \pm 10$ & $55 \pm 9$ & $54 \pm 11$ \\
\hline \multicolumn{4}{|l|}{ Left ventricular ejection fraction } \\
\hline Acute $(\%)$ & $51 \pm 11$ & $55 \pm 10$ & $49 \pm 13$ \\
\hline Day $7(\%)$ & $52 \pm 11$ & $52 \pm 10$ & $51 \pm 14$ \\
\hline \multicolumn{4}{|l|}{ Infarct zone regional wall motion } \\
\hline Acute (SD / chord) & $-2.56 \pm 1.07$ & $-2.59 \pm 1.00$ & $-2.36 \pm 1.21$ \\
\hline Day 7 (SD / chord) & $-2.12 \pm 1.24$ & $-2.69 \pm 1.05$ & $-2.02 \pm 1.26$ \\
\hline \multicolumn{4}{|l|}{ Events after discharge (\%) } \\
\hline Death & 3 & 0 & 5 \\
\hline Nonfatal myocardial infarction & 5 & 9 & 2 \\
\hline Coronary angioplasty & 8 & 6 & 7 \\
\hline Coronary artery bypass surgery & 5 & 13 & 4 \\
\hline $\begin{array}{l}\text { Time to follow-up (months) } \\
\quad(\text { mean } \pm \text { SD) }\end{array}$ & $19+8$ & $20+8$ & $18+7$ \\
\hline
\end{tabular}

recurrent myocardial ischemia was associated with excellent long-term survival and a low incidence of late recurrent ischemic events. A progressive decline in the incidence of death from coronary artery disease has been documented over the past 2 decades ${ }^{5,14,15}$ and has been attributed to both the primary prevention of coronary artery disease and a decrease in periinfarction mortality. ${ }^{14,15}$ Our results suggest that early reperfusion therapy has not only further decreased periinfarction mortality but has also substantially improved long-term postinfarction survival. The patients in this study do represent a relatively low-risk cohort since elderly patients, those in cardiogenic shock and patients presenting late after the onset of their symptoms were excluded from enrollment. Nonetheless, the out-of-hospital survival of this TAMI population compares favorably with that of similar cohorts of patients treated with less aggressive therapeutic regimens.

Mortality after thrombolysis: Two large, placebocontrolled thrombolytic trials have used conservative postlytic strategies. In the Gruppo Italiano per lo Studio della streptochinasi nell'infarto miocardico (GISSI) study, ${ }^{16}$ streptokinase therapy was associated with a $10 \%$ decrease in cumulative 1-year mortality from 19.0 to $17.2 \%(p=0.008)$. The decrease in mortality was particularly striking for patients treated within 1 hour of the onset of symptoms ( 12.9 vs $21.2 \%, p=0.00001$, relative risk $=0.6)$. A similar decrease in cumulative 2year mortality was noted in each subgroup of the second International Study of Infarct Survival (ISIS-2), ${ }^{2}$ from $19.0 \%$ in the control group to $13.5 \%$ in the group receiving streptokinase and aspirin. In both studies, the survival curve of the patients treated with thrombolytic therapy paralleled that of the respective control groups suggesting that the principal impact of thrombolytic therapy on survival occurred during the acute, hospital phase.

Combined pharmacologic and mechanical reperfusion therapy: In contrast to the above 2 trials in which predischarge coronary angioplasty or bypass graft surgery were rarely performed, the TAMI study protocol evaluated a strategy of intravenous thrombolysis, acute- phase coronary angiography and, in a large proportion of the patient population, urgent coronary angioplasty and/or coronary artery bypass surgery. Elective revascularization procedures were also performed in a relatively high proportion of the patients before hospital discharge. This strategy has the theoretical advantages of maximizing infarct vessel patency and the extent of myocardial salvage, of decreasing the likelihood of infarct vessel reocclusion and reinfarction, and of preserving function of the non-infarct zone in patients with multivessel disease. Using this intensive revascularization strategy, the out-of-hospital mortality in this study was only $3.3 \%$ at a mean follow-up of 18.8 months, with a cardiovascular mortality of $2.1 \%$. The incidence of nonfatal reinfarction was $5.1 \%$ which is comparable to that of other studies. ${ }^{16-18}$ Similar postlytic strategies were used by Stack $^{19}$ and Kander ${ }^{20}$ and their colleagues. The 1-year survival was $94 \%$ in the former study and, in the latter, the 2-year survival was $93.6 \%$ and correlated with infarct vessel patency, left ventricular ejection fraction and the absence of prior myocardial infarction. Comparable 1-year survival rates have also been reported after direct coronary angioplasty. ${ }^{21}$

Three randomized trials have directly compared an "invasive" postlytic revascularization strategy with a more conservative approach. $22-24$ Cumulative 1 -year mortality was $6.9 \%$ in the invasive group of the TIMI $2 \mathrm{~B}$ study compared with $7.5 \%$ in the conservative group. ${ }^{22}$ It should be noted, however, that elective revascularization procedures were performed in a relatively high proportion of the conservative strategy group (37\%) during the follow-up period. Low 90-day mortality rates have also been reported for both groups of the "Should We Intervene Following Thrombolysis?" trial ( 3.2 vs $4.8 \%$ ). ${ }^{23}$ Patients enrolled in this study were $\leq 70$ years old, presented within 3 hours of the onset of symptoms of their first myocardial infarction and required 24 hours of clinical stability to be eligible for randomiza. tion. Thus, they also represent a low-risk population and any difference in long-term survival between the 2 postlytic strategies is likely to be small. In the European Coopcrative Study, ${ }^{24}$ 1-year mortality was actually 
somewhat higher after tPA with immediate PTCA (9.6\%) compared with thrombolysis alone $(5.5 \%)$ but the difference did not reach statistical significance.

Surgical reperfusion: Perhaps the most direct method of rapidly achieving myocardial revascularization is by emergency coronary artery bypass graft surgery. A long-term study of surgical reperfusion therapy for acute myocardial infarction was recently reported by DeWood et al. ${ }^{25}$ When compared with a similar group of patients treated with conventional medical therapy, the overall 13-year actuarial mortality rate was significantly decreased ( 27 vs $41 \%, \mathrm{p}=0.0007$ ).

Mechanisms of improved survival after reperfusion therapy: Several mechanisms are likely to contribute to the improved survival after reperfusion therapy. Patency of the infarct-related artery has been associated with significant improvement in long-term survival even in the absence of an improvement in left ventricular function. ${ }^{19,26-28}$ Possible explanations for this observation include a decreased incidence of left ventricular aneurysm formation independent of the extent of myocardial salvage, ${ }^{29}$ greater electrical stability of the injured myocardium, ${ }^{30,31}$ a decrease in left ventricular mural thrombus formation $^{32}$ and the provision of a conduit for later recruitment of a collateral vascular supply to the contralateral myocardium. Somewhat surprisingly, in this study there were no deaths during the follow-up period in the group of patients discharged from hospital with an occluded infarct vessel. In comparison, although they had significantly better regional infarct zone wall motion and an improvement rather than deterioration in global left ventricular function, the group with patent infarct-related arteries had a 3\% mortality. The cause of this discrepancy is unclear. One final mechanism should be considered. It has been suggested ${ }^{33}$ that the improved out-of-hospital survival in patients treated aggressively may be due to the accelerated and premature death of high-risk patients before hospital discharge. In this study, however, the overall in-hospital mortality was only $6.5 \%$ which is comparable to that of other large thrombolytic trials including those with conservative postthrombolysis protocols.

Study limitations; All long-term follow-up studies are limited by incomplete data collection and the possibility of underreporting of event rates during the followup period. The survival status of 30 patients of the original cohort discharged from hospital is unknown. Theoretically, therefore, the actual mortality rate could be as high as $7 \%$. This problem is not unique to this study and the $96 \%$ follow-up obtained is comparable to that achieved in other large, multicenter studies. A second limitation is the absence of a control population that may have permitted more definite conclusions about the value of this therapeutic approach. Finally, conclusions drawn from this study cannot be applied to the large proportion of the myocardial infarction population excluded from eligibility from this trial because of advanced age, late presentation or contraindications to thrombolysis. Further systematic evaluation is required to better define optimal treatment strategies and the prognosis for long-term postinfarction survival of these important groups of patients.

\section{REFERENCES}

1. Gruppo Italiano per lo studio della streptochinasi nell'infarto miocardico (GISSI). Effectiveness of intravenous thrombolytic treatment in acute myocardial infarction. Lancet 1986;1:397-402.

2. ISIS-2 Collaborative Group. Randomized trial of intravenous streptokinase, oral aspirin, both or neither among 17187 cases of suspected acute myocardial infarction: ISIS-2. Lancet 1988:2:349-360.

3. Wilcox RG, Olsson CG, Skene AM, von der Lippe G, Jensen G, Hampton JR, for the ASSET Study Group. Trial of tissue plasminogen activator for mortality reduction in acute myocardial infarction. Anglo-Scandinavian Study of Early Thrombolysis (ASSET). Lancet 1988;2:525-530.

4. The TIMI Study Group: Comparison of invasive and conservative strategies after treatment with intravenous tissue plasminogen activator in acute myocardial infarction. Results of the Thrombolysis in Myocardial Infarction (TIMI) phase II trial. $N$ Engl J Med 1989;320:618-627.

5. Kannel WB, Sorlie P, McNamara PM. Prognosis after initial myocardial infarction: The Framingham Study. Am J Cardiol 1979;44:53-59.

6. Topol EJ. An overview of the Thrombolysis and Angioplasty in acute Myocardial Infarction (TAMI) trials. Arch Mal Coeur 1988;81:45-49.

7. Tupol EJ, Califf RM, George BS, Kereiakes DJ, Abboltsmith CW, Candela RJ, Lee KL, Pitt B, Stack RS, O'Neill WW, and the TAMI Study Goup. A randomized trial of immediate versus delayed elective angioplasty after intravenous tissue plasminogen activator in acute myocardial infaretion. $N \mathrm{Engl} \mathrm{J} \mathrm{Med}$ 1987;317:581-588

8. Topol EJ, Califf RM, George BS, Kereiakes DJ, Rothbaum D, Candela RJ, Abbottsmith CW, Pinkerton CA, Stump DC, Collen D, Lee KL, Pitt B, Kline EM, Boswick JM, O'Neill WW, Stack RS and the TAMI Study Group. Coronary arterial thrombolysis with combined infusion of recombinant tissue-type plasminogen activator and urokinase in patients with acute myocardial infarction. Circulation 1988:77:1100-1107.

9. Topol EJ, George BS, Kereiakes DJ, Stump DC, Candela RJ, Abbottsmith CW, Aronson L, Pickel A, Boswick JM, Lee LK, Ellis SG, Califf RM. A randomizcd controlled of intravenous tissuc plasminogen activator and carly intravenous heparin in acute myocardial infarction. Circulation 1989,79:281-286 10. Wall TC, Phillips HR, Stack RS, Mantell S, Aronson L, Boswick J, Sigmon K, DiMeo M, Chaplin D, Whitcomb D, Pasi D, Zawodniak M, Hajisheik M, Hegde S, Barker W, Tenney R, Califf RM. Results of high dose intraveous urokinase for acute myocardial infarction. Am J Cardiol 1990;65:124-13J. 11. Topol EJ, Ellis SG, Califf RM, George BS, Stump DC, Bates ER, Nabel EG Walton JA, Candela RJ, Lee KL, Kline EM, Pitt B, the Thrombolysis and Angioplasty in Myocardial Infarction (TAMI) 4 Study Group. Combined tissuetype plasminogen activator and prostacyclin therapy for acute myocardial infarction. $J$ Am Coll Cardiol 1989;14:877-884.

12. Califf RM, Topol EJ, George BS, Kereiakes DJ, Aronson LG, Lee KL Martin L, Candela R, Abbottsmith C, O'Neill WW, Pryor DB, Stack RS, and the TAMI Study Group. One year outcome after therapy with tissue plasminogen activator: Report from the Thrombolysis and Angioplasty in Myocardial Infarction trial. Am Heart J 1990;119:777-785.

13. Kereiakes DJ. Topol EJ, George BS, Abbottsmith CW, Stack RS, Candela RJ, O'Neill WW, Martin LH, Califf RM, and the TAMI Study Group. Emergency coronary artery bypass surgery preserves global and regional left ventricular function after intravenous tissue plasminogen activator therapy for acute myocardial infarction. $J$ Am Coll Cardiol 1988:11:899-907.

14. Kuller LH, Travern ND, Rutan GH, Perper JA, Ives DG. Marked decline of coronary heart disease mortality in 35-44 year old white men in Alleghany County, Pennsylvania. Circulation 1989,80:261-266.

15. The Multicenter Postinfarction Research Group. Risk stratification and survival after myocardial infarction. $N$ Engl J Med 1983;309:331-336.

16. Gruppo. Italiano per lo studio della streptochinasi nell'infarto miocardico (GISSI). Long-term effects of intravenous thrombolysis in acute myocardial infarction: final report of the GISSI study. Lancet 1987;2:871-874.

17. Dwyer EM, McMaster P, Greenberg H, Multicenter Postinfarction Research Group. Nonfatal cardiac events and recurrent infaretion in the year after acute myocardial infarction. I Am Coll Cardiol 1984:4:695-702.

18. Dalen JE, Gore JM, Braunwald E, Borer J, Goldberg RJ, Passamani ER, Forman S, Knatterund G, TIMI Investigators. Six and twelve month follow-up of the phase 1 Thrombolysis in Myocardial Infarction (TIMI) trial. Am J Cardiol 1988,62:179-185.

19. Stack RS, Califf RM, Hinohara T, Plillips HR, Pryor DB, Simonton CA Carlson EB, Morris KG, Behar VS, Kong Y, Peter RH, Hlatky MA, O'Connor $\mathrm{CM}$, Mark DB. Survival and cardiac event rates in the first year after emergency coronary angioplasty for acute myocardial infarction. $J \mathrm{Am}$ Coll Cardiol 1988:11:1141-1149.

20. Kander NH, O'Neill W, Topol EJ, Gallison L, Mileski R, Ellis SG. Longterm follow-up of patients treated with coronary angioplasty for acute myocardial infarction. Am Heart J 1989;118:228-233. 
21. O'Keefe JH, Rutherford BD, McConahay DR, Ligon RW, Johnson WL, Giorgi LV, Crockett JE, McCallister BD, Conn RD, Gura GM, Good TH, Steinhaus DM, Bateman TM, Shinshak TM, Hartzler GO. Early and late results of coronary angioplasty without antecedent thrombolytic therapy for acute myocardial infarction. Am J Cardiol 1989,64:1221-1230.

22. Baim DS, Braunwald E, Feit F, Knatterund GL, Passamani ER, Robertson TL, Rogers WJ, Solomon RF, Williams DO. The Thrombolysis in Myocardial Infarction (TIMI) Trial Phase II: additional information and perspectives. $J$ Am Coll Cardiol 1990;15:1188-1192.

23. The SWIFT Trial Study Group. The SWIFT trial of delayed elective intervention vs a conservative treatment policy after thrombolysis with anistreplase in acute myocardial infarction. Lancet 1990 , in press.

24. Simoons ML, Arnold A. One year follow-up of rtPA without and with immediate PTCA (abstract). Circulation 1989;(suppl II)80:II-520.

25. DeWood MA, Leonard J, Grunwald RP, Hensley GR, Mouser LT, Burroughs RW, Berg R J $\mathbf{J}_{\mathrm{r}}$, Fisher LD. Medical and surgical management of early Q wave myocardial infarction. II. Effects on mortality and global and regional left ventricular function at 10 or more years of follow-up. $J \mathrm{Am}$ Coll Cardiol $1989 \cdot 14: 78-90$.

26. Ritchie JL, Davis KB, Williams DL, Caldwell J, Kennedy JW. Global and rcgional left ventricular function and tomographic radionuclide perfusion: the Western Washington Intracoronary Streptokinase in Myocardial Infarction Tri- al. Circulation $1984 ; 70: 867-875$.

27. Cigarroa RG, Lange RA, Hillis LD. Prognosis after myocardial infarction in patients with and without residual antegrade coronary blood flow. Am J Cardiol $1989 ; 64: 155-160$.

28. Mathey DG, Schofer J, Sheehan FH, Krebber H, Justen M, Rodewald G, Dodge HT, Bleifeld $W$. Improved survival up to four years after early coronary thrombolysis. Am J Cardiol 1988;61:524-529.

29. Hochman J, Choo H. Limitation of myocardial infarct expansion by reperfusion independent of myocardial salvage. Circulation 1987.75:299-306.

30. Sager PT, Perlmutter RA, Rosenfeld LE, McPherson CA, Wackers FJTh, Batsford WP. Electrophysiologic effects of thrombolytic therapy in patients with a transmural anterior myocardial infarction complicated by left ventricular aneurysm formation. $J$ Am Coll Cardiol 1988:12:19-24.

31. Kersschot IE, Brugada $P$, Ramentol M, Zehender M, Waldecker B, Stevenson WG, Geibel A, De Zwaan C, Wellens HJJ. Effects of early reperfusion in acute myocardial infaretion in arrhythmias induced by programmed stimulation: a prospective, randomized study. J Am Coll Cardiol 1986;7:1234-1242.

32. Eigler N, Maurer G, Shah PK. Effect of early systemic thrombolytic therapy on left ventricular thrombus formation in acute anterior myocardial infarction Am J Cardiol 1984;54:261-263.

33. Topol EJ. The long-term investment of coronary angioplasty for acute myocardial infarction. $J$ Am Coll Cardiol 1988:11:1150-1152. 